\title{
A Study of Performance Output of a Multivane Air Engine Applying Optimal Injection and Vane Angles
}

\author{
Bharat Raj Singh ${ }^{1}$ and Onkar Singh ${ }^{2}$ \\ ${ }^{1}$ Department of Mechanical Engineering, SMS Institute of Technology, Kashimpur Biruha, Lucknow 227125, India \\ ${ }^{2}$ Department of Mechanical Engineering, Harcourt Butler Technological Institute, Nawabganj, Kanpur 208002, India
}

Correspondence should be addressed to Bharat Raj Singh, brsinghlko@yahoo.com

Received 5 October 2011; Revised 12 March 2012; Accepted 15 March 2012

Academic Editor: Mustafa Canakci

Copyright ( 2012 B. R. Singh and O. Singh. This is an open access article distributed under the Creative Commons Attribution License, which permits unrestricted use, distribution, and reproduction in any medium, provided the original work is properly cited.

\begin{abstract}
This paper presents a new concept of the air engine using compressed air as the potential power source for motorbikes, in place of an internal combustion engine. The motorbike is proposed to be equipped with an air engine, which transforms the energy of the compressed air into mechanical motion energy. A mathematical model is presented here, and performance evaluation is carried out on an air-powered novel air turbine engine. The maximum power output is obtained as $3.977 \mathrm{~kW}(5.50 \mathrm{HP})$ at the different rotor to casing diameter ratios, optimal injection angle $60^{\circ}$, vane angle $45^{\circ}$ for linear expansion (i.e., at minimum air consumption) when the casing diameter is kept $100 \mathrm{~mm}$, at injection pressure 6 bar ( $90 \mathrm{psi}$ ) and speed of rotation $2500 \mathrm{rpm}$. A prototype air engine is built and tested in the laboratory. The experimental results are also seen much closer to the analytical values, and the performance efficiencies are recorded around 70\% to $95 \%$ at the speed of rotation $2500-3000 \mathrm{rpm}$.
\end{abstract}

\section{Introduction}

As per recent survey in the populationwise largest state of Uttar Pradesh, India, there are more than 10.5 millions transport vehicles out of which about 8.2 millions are two wheelers/motorbikes, mostly driven by internal combustion (IC) engines. The total transport vehicles are generating about $77.8 \%$ air pollutants such as: carbon monoxide (CO), carbon dioxide $\left(\mathrm{CO}_{2}\right)$, and unburned hydrocarbon $(\mathrm{HC})$, out of which $80 \%$ pollutants is generated by motorbikes and released to the atmosphere. The study shows that the IC engines of motorbikes may generate up to two times more pollutants than those of automobiles. In order to reduce the air pollution and eliminate $50-60 \%$ of the emitted pollutants, this paper presents a new concept of an air engine using compressed air as the potential power source for motorbikes instead of an IC engine. Such motorbike is proposed to be equipped with an air engine, which transforms the energy of the compressed air into mechanical motion energy.

The number of transport vehicles is increasing across the world every year and resulting into rapid and huge consumption of fossil-fuel quantities, thereby causing a threat to fast depletion to energy resources. A noted geophysicist Marion King Hubbert [1] was the first man who effectively applied the principles of geology, physics, and mathematics in 1956 for the future projection of oil production from the US reserve base. Hubbert indicated that conventional crudeoil production would attain peak oil in 1970 and thereafter start depleting. This may cause a serious threat to mankind within 40 years, that is, by 1995. This will also affect the environment due to release of huge quantities of a pollutant in the atmosphere. Aleklett and Campbell [2] indicated in 2003 that the world is depleting its resources of oil and gas at such a rate that oil production is set to peak and begins to decline by around 2010. This apprehension necessitates the search for environment friendly alternative to fossil-fuel oil or some method of conserving natural resources using nonconventional options, such as biodiesel, wind power, and photo voltaic cells and or some energy conversion systems like battery storage, hydrogen cell, and compressed air to obtain shaft work for the engines of vehicles [3-9].

Compressed air has the enormous potential as an alternative to these issues due to its zero pollutant capability and for running prime mover like air turbine. Pioneering work in 
the area of the compressed air engine has been done by French technologist Guy and Cyril [10] and also by an inventor of quasi turbine Saint Hilaire et al. [11]. Use of compressed air as working fluid offers a prime mover which does not involve a combustion process for producing shaft work. Thus, the great advantages in terms of availability of air as fuel and the emissions free from carbon dioxide, carbon monoxide, and nitrous oxides are apparent to such air motors. Compressed air driven prime-movers are also found to be cost effective compared to fossil-fuel-driven engines. It has the perennial compressed air requirement which needs some source of energy for running compressor whose overall analysis shows that the compressed air system is a quite good option for light vehicle applications [12]. In view of these attractive features, the compressed air engine may become the dominant technology in place of the electric and hydrogen cell in the vehicle market.

Detailed study has been carried out about multivane expander for its various parameters such as: geometry, end friction, optimizing the efficiency [13-22], and pneumatic hybrid power system [23-26]. The work of pressure regulation of turbine, performance efficiency of Rankine cycle, multistage turbine compressor models, experimental investigation on rotary vane expander, three-stage expander into a $\mathrm{CO}_{2}$ refrigeration system, endface friction of the revolving vane mechanism, and design and implementation of an airpowered motorcycle have also been reviewed [27-33] .

This paper focuses on the study of influence of rotor/ casing dimension on the performance of an air turbine proposed to be equipped on motorbikes in place of an internal combustion engine. The mathematical modeling and performance evaluation of various parameters of such a small capacity compressed air-driven turbine was carried out earlier [34-50]. In this study, the effect of isobaric admission and adiabatic expansion of high-pressure air for different rotor diameters, casing diameters, and rotor/casing diameter ratios $(d / D)$ of the turbine have been considered and analyzed for linear expansion (i.e., for moderate air consumption).

\section{Concept of Air Turbine Model}

This study proposes a multivanes type air turbine as shown in Figure 1. Such air turbine is considered to work on the reverse working principle of vane type compressor. In this arrangement total shaft work is cumulative effect of isobaric admission of compressed air jet on vanes and the adiabatic expansion of high-pressure air.

The total shaft power of the air turbine is cumulative effect of isobaric admission of compressed air jet on vanes and the adiabatic expansion of high pressure air. A prototype of air turbine was developed and its functionality was ensured [12] in the earlier study of authors. Vanes of novel air turbine were placed under spring loading to maintain their regular contact with the casing wall to minimize leakage. A cylinder for the storage of compressed air with a minimum capacity of storing air for the requirement of $30 \mathrm{~min}$ running at initial stage and maximum pressure of 20 bar is used as a source of compressed air. The storage container has a

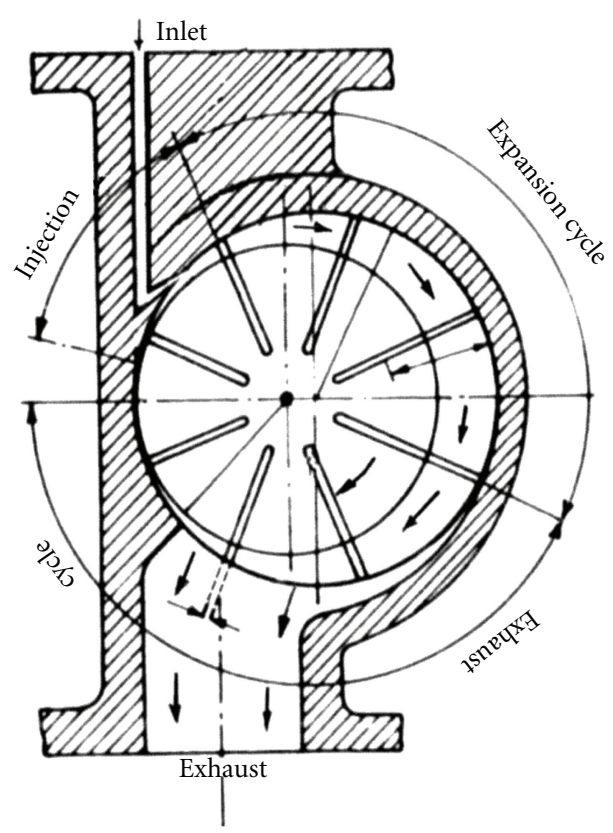

Figure 1: Air-turbine model.

capacity of 250 Ltrs $(8.8 \mathrm{cuft})$ at atmospheric pressure and can attain 5000 Ltrs ( 176 cuft) of atmospheric air, when filled up to test pressure of $20 \mathrm{bar}=\left(20.4 \mathrm{Kg} f / \mathrm{Cm}^{2}\right)$. The air turbine considered has capability to yield output of 5.50 to $6.80 \mathrm{HP}$ at $4-6$ bar air pressure and for speed of 2000$2500 \mathrm{rpm}$, which is suitable for a motorbike.

The present objective of this study is to investigate the performance of an air turbine with the variation of rotor/ casing dimensions with minimum air consumption and its experimental validation.

\section{Mathematical Modeling}

The mathematical model shown here is already presented in the author's earlier publication [48], but it is again reproduced in brief for the benefits of readers. In this rotary machine, the high-pressure air jet at ambient temperature drives the rotor of air turbine due to both isobaric admission and adiabatic expansion. When high-pressure air enters through the inlet passage, pushes the vane for producing rotational movement through this vane, and thereafter air so collected between two consecutive vanes of the rotor is gradually expanded up to exit passage. This isobaric admission and adiabatic expansion of high-pressure air both contribute in producing the shaft work from air turbine. The expanded air leaving the air turbine after expansion is sent out from the exit passage. It is assumed that the scavenging of the rotor is perfect, and the work involved in recompression of the residual air is absent.

From Figure 2, it is seen that work output is due to isobaric admission (E to 1), adiabatic expansion (1 to 4) and steady exit flow work (4 to 5). Thus, total power output 
TABLE 1: Input parameters.

\begin{tabular}{ll}
\hline Symbols & Parameters \\
\hline Rotor to casing $(d / D)$ ratio & $0.95,0.9,0.85,0.80,0.75,0.70,0.65,0.60$, and 0.55, when casing diameters are kept $D=100$ mm \\
$p_{1}$ & 2 bar $(\approx 30 \mathrm{psi}), 3$ bar $(\approx 45 \mathrm{psi}), 4$ bar $(\approx 60 \mathrm{psi}), 5$ bar $(\approx 75$ psi $), 6$ bar $(\approx 90$ psi $)-i n l e t$ pressures \\
$p_{4}$ & $\left(v_{1} / v_{4}\right)^{\gamma} \cdot p_{1}<p_{5}$ assuming adiabatic expansion \\
$p_{5}$ & $\left(p_{4} / 1.1\right)=1.0132$ bar-exit pressure \\
$N$ & $2500 \mathrm{rpm}$ \\
$L$ & $45 \mathrm{~mm}$ length of rotor (assumed minimum $)$ \\
$n$ & $(360 / \theta)$ number of vanes in rotor \\
$\gamma$ & 1.4 for air \\
$\theta$ & $45^{\circ}$ angle between 2 vanes (i.e., rotor contains correspondingly 8 number of vanes $)$ \\
$\phi$ & $60^{\circ}$, injection angle at which air enters into turbine \\
\hline
\end{tabular}

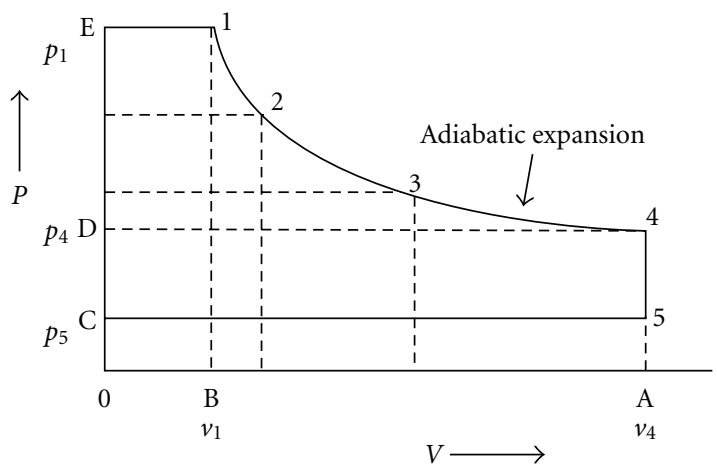

Figure 2: Thermodynamic processes (isobaric, adiabatic, and isochoric expansion).

(work done per unit time) $W$, for speed of rotation $N \mathrm{rpm}$ due to thermodynamic processes may be written as [51]:

$$
\begin{aligned}
W_{\text {total }}= & n \cdot\left(\frac{N}{60}\right) \cdot\left(\frac{\gamma}{\gamma-1}\right) \cdot p_{1} \cdot v_{1} \cdot\left\{1-\left(\frac{p_{4}}{p_{1}}\right)^{(\gamma-1) / \gamma}\right\} \\
& +n \cdot\left(\frac{N}{60}\right) \cdot\left(p_{4}-p_{5}\right) \cdot v_{4},
\end{aligned}
$$

where $W_{\exp }=n \cdot(N / 60) \cdot(\gamma /(\gamma-1)) \cdot p_{1} \cdot v_{1} \cdot\{1-$ $\left.\left(p_{4} / p_{1}\right)^{(\gamma-1) / \gamma}\right\}$ and $W_{\text {flow }}=n \cdot(N / 60) \cdot\left(p_{4}-p_{5}\right) v_{4}$.

It is seen that if vanes are at angular spacing of $\theta$ degree, then total number of vanes will be $n=(360 / \theta)$.

\section{Assumptions and Investigation Parameters}

Following assumptions and investigation parameters are taken while analyzing the air engine performance.

(i) The temperature of compressed air entering through inlet into rotor and casing space is at ambient temperature.

(ii) Vanes are spring loaded and hence leakages across vane tip and casing liner are ignored.

(iii) Friction between vane tip and casing liner is ignored.
Various input parameters are considered as shown in Table 1 for investigation. The effect of speed of rotation, rotor/casing diameter ratio, and injection pressure on the expansion power output, flow work output, and total power output from air turbine is studied. Here the vane angle $\theta$, injection angle $\phi$, and speed of rotation $N$ of the air turbine are considered to be constant for whole study. The results obtained have been plotted in Figures 3-7, for the rotor/ casing diameter ratio $(d / D)$, varied as $0.95,0.90,0.85,0.80$, $0.75,0.65,0.60$, and 0.55 at vane angle of $45^{\circ}$, injection angle of $60^{\circ}$ at different injection pressures of $2-6$ bar $(30,45,60$, 75 , and $90 \mathrm{psi}$ ) and at the speed of rotation $2500 \mathrm{rpm}$, at casing diameter $100 \mathrm{~mm}$.

\section{Results and Discussions}

5.1. Theoretical Results. Figure 3 shows the variation of expansion power at different rotor/casing diameter ratios with respect to different injection pressure. It is evident that the shaft power due to expansion at 2 bar is lower at higher rotor/ casing diameter ratio of 0.95 , thereafter gradually increases linearly up to 0.75 to 0.70 and becomes largest when rotor/ casing diameter ratio is kept 0.55 . For higher injection pressure 4 to 6 bar, this is attributed to the large power output in similar pattern.

It is learnt that there exists maximum rotor/casing diameter for every injection pressure which offers the linear expansion power at moderate air consumption and beyond 0.70 to 0.55 rotor/casing $(d / D)$ ratios, the value of maximum expansion power is more, but expansion is parabolic which shows the higher air consumption for higher shaft output. The higher injection pressures produce higher shaft power in similar manner as compared to lower injection pressures.

Figure 4 shows the variation of exit flow power at different rotor/casing diameter ratios with respect to different injection pressure. It is seen that the shaft power due to exit flow work is lowest at 2 bar and parabolically increases up to rotor/casing diameter ratio of 0.55 . It is quite evident that the shaft power due to exit flow work gradually increases with reducing value of rotor/casing diameter ratio in view of the gap between the rotor and casing as increases gradually. That is why the exit flow power is nearly insignificant for 


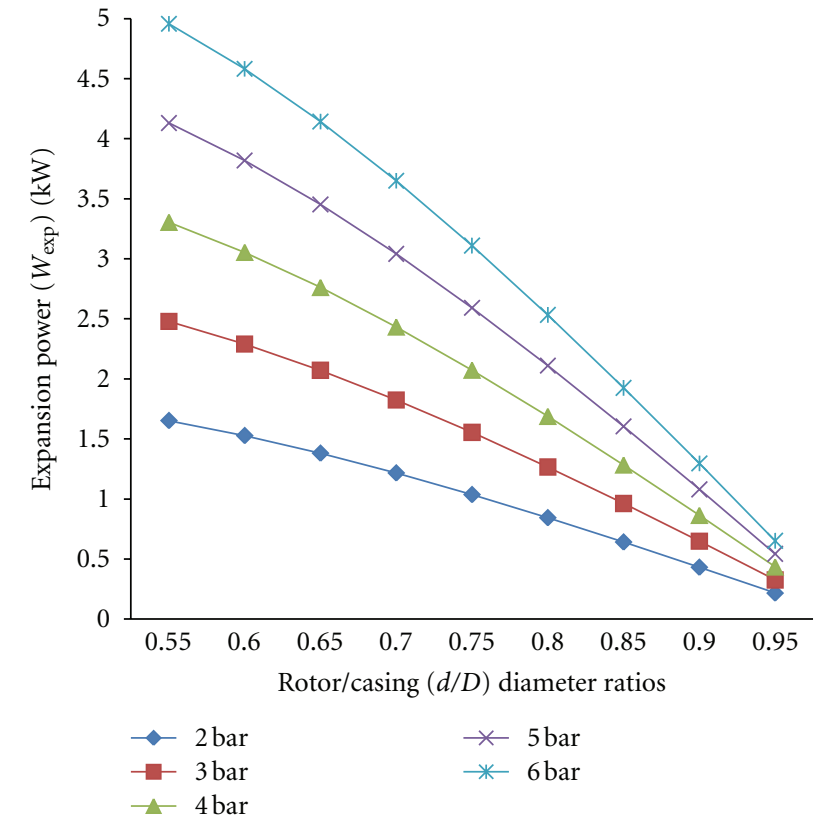

FIGURE 3: Expansion power versus rotor/casing diameter $(d / D)$ ratio when $D=100 \mathrm{~mm}$.

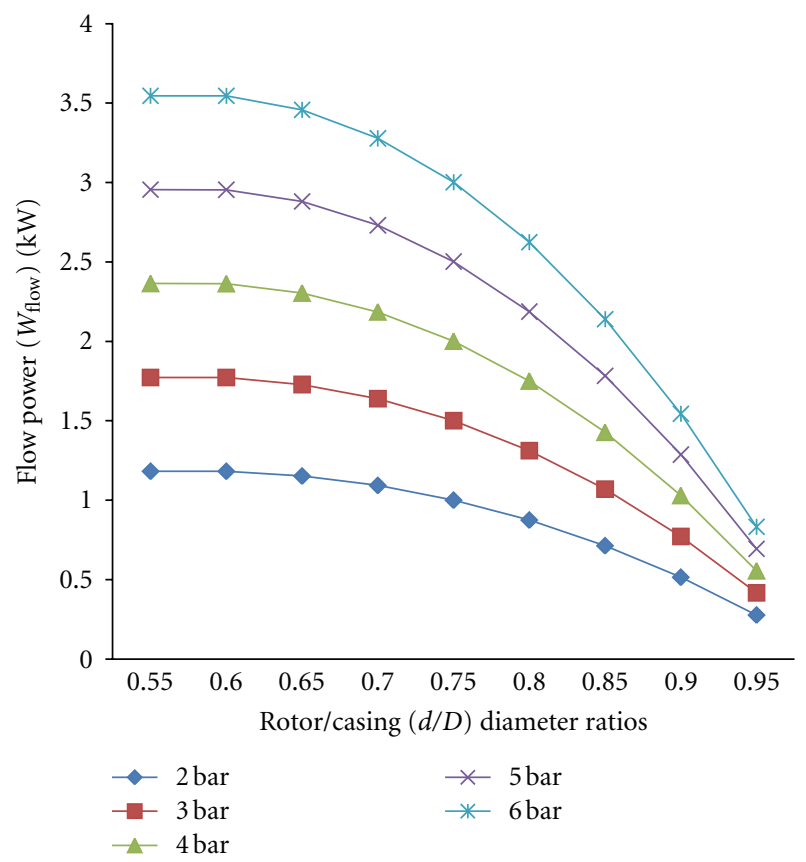

FIGURE 4: Exit flow power versus rotor/casing diameter $(d / D)$ ratio when $D=100 \mathrm{~mm}$.

rotor/casing diameter ratio of 0.95 and would be absent when this ratio value is unity.

Figure 5 shows the percentage contribution of expansion power against total work output at different rotor/casing diameter ratios with respect to different injection pressure. It is evident that percentage contribution of expansion power is lower at $d / D$ ratio $=0.95$ and highest at $d / D=0.55$ for all injection pressure 2-6 bar. At rotor/casing ratio 0.95 the

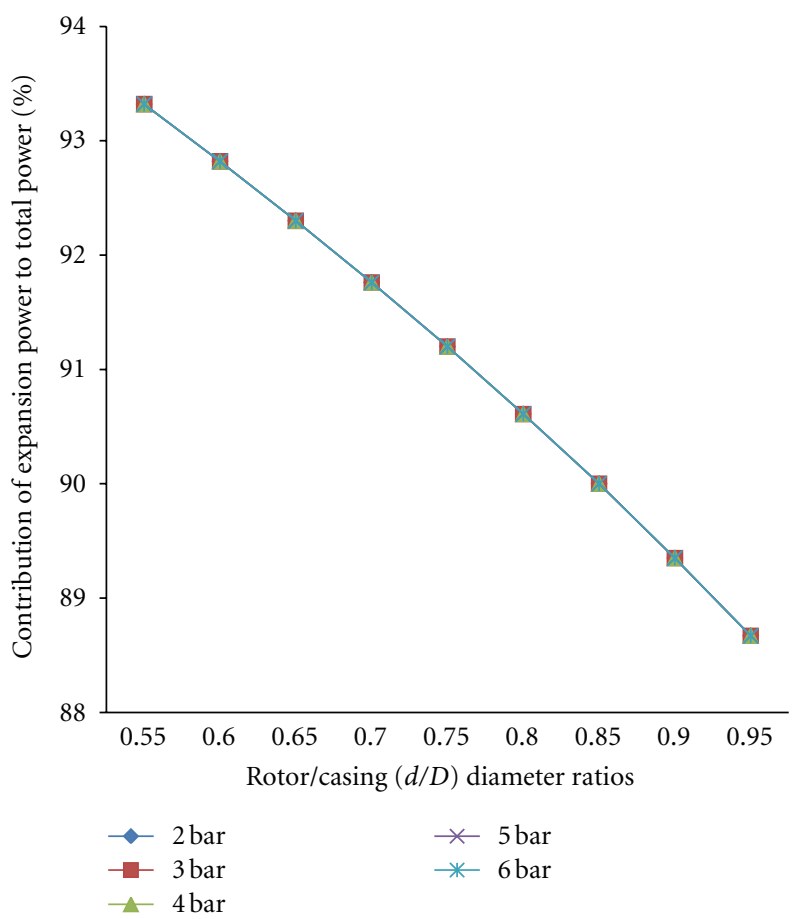

FIGURE 5: Percentage contribution of expansion power versus rotor/ casing diameter $(d / D)$ ratio, when $D=100 \mathrm{~mm}$.

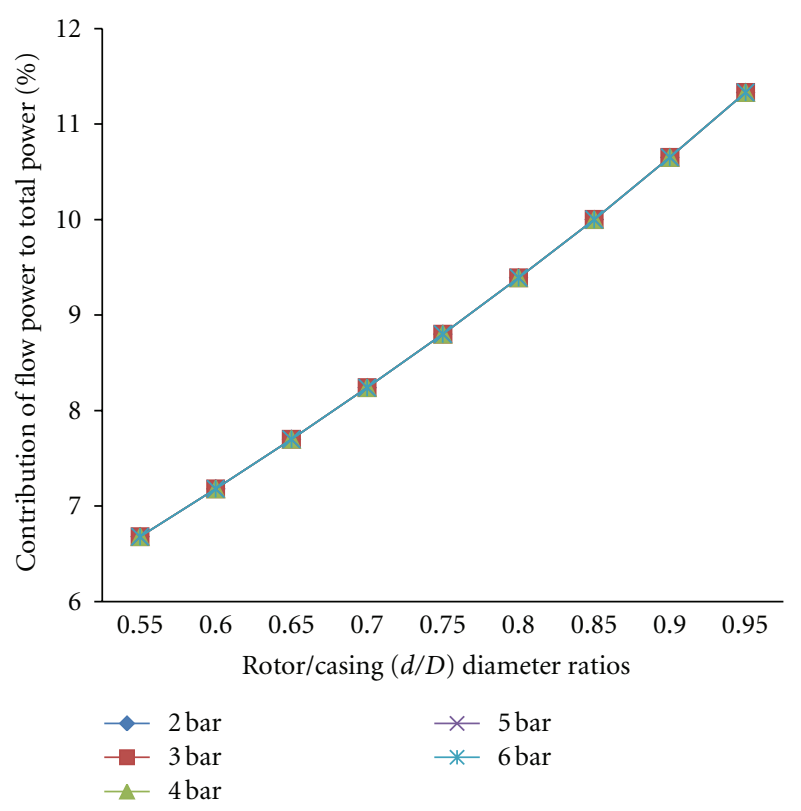

Figure 6: Percentage contribution of exit flow power versus rotor/ casing diameter $(d / D)$ ratio when $D=100 \mathrm{~mm}$.

contribution of expansion power against total power is lowest and gradually increases from $88.67 \%$ to $93.32 \%$ as rotor/ casing diameter ratio decreases from 0.95 to 0.55 .

Figure 6 shows the percentage contribution of exit flow power in total power output at different rotor/casing diameter ratios with respect to different injection pressure. It is 
evident that percentage contribution of exit flow power is higher, when rotor/casing diameter ratio is 0.95 and gradually decreases from $11.33 \%$ to $6.68 \%$ as this diameter ratio drops up to 0.55 when casing diameter is kept $100 \mathrm{~mm}$ at all injection pressure from 2-6 bar.

Figure 7 shows the total power output with respect to different rotor/casing diameter ratios and different injection pressure 2-6 bar. At injection pressure 2-6 bar total power is seen increasing linearly from rotor/casing diameter ratio 0.95 to 0.70 . It further increases parabolically but produces larger value of power, when rotor/casing diameter ratio reaches to 0.55 and such trend of graph confirms the higher air consumption. Thus for minimum air consumption, the optimal shaft power output is obtained as $3.977 \mathrm{~kW}$ at rotor/ casing diameter ratio 0.70, 6-bar injection pressure and $2500 \mathrm{rpm}$ speed of rotation as seen in the graph till it is straight line.

From the above, it is obvious that the expansion power output as well as total power output is found maximum as 3.6495 and $3.977 \mathrm{~kW}$, respectively, for moderate/minimum air consumption when rotor/casing diameter ratios lie between 0.75 to 0.70 at casing diameter $100 \mathrm{~mm}$.

5.2. Experimental Results. The complete schematic of test setup is shown in Figure 8. It consists of compressor, compressed air storage cylinder, supply of compressed air through air filter, and regulator and lubricator to air turbine. The dynamometer consisting of load pulley, weight load, and load dial gauge are also shown in the set up.

The experimental setup consisting of a heavy duty twostage compressor with suitable air storage tank, air filter, regulator and lubricator, novel air turbine, and rope dynamometer has been created for validation of theoretical results.

The actual setup of test rig of air engine/turbine was fabricated and air turbine was tested in the laboratory. The compressed air is produced by a heavy duty two-stage compressor and stored in a suitable capacity of air tank to maintain nearly constant supply pressure of 300 psi. The compressed air is connected to air filter, regulator, and lubricator to produce desired air pressure for testing. The data is recorded with various parametric conditions and performance evaluation of the prototype air turbine is carried out.

Performance evaluation is conducted on a compressed air-driven vaned-type novel air turbine. The comparison of theoretical total shaft outputs with respect to experimental values are carried out on following optimum input parameters such as high-pressure air $1.4 \mathrm{bar}$ (20 psi), $2.8 \mathrm{bar}$ (40 psi), 4.2 bar (60 psi), 5.6 bar ( $80 \mathrm{psi})$, and 7 bar (100 psi), at different input parameters (injection angle $60^{\circ}$, vane angle $45^{\circ}, L=45 \mathrm{~mm}$, and $d=75 \mathrm{~mm}$ rotor diameter and $D=$ $100 \mathrm{~mm}$ casing diameter (or $d / D=0.75$ ).

Figure 9 shows that the theoretical power at different speed of rotation is increasing with increase of injection pressure. The rate of increase of power is higher at higher injection pressure compared to lower injection pressure. This can be attributed to the fact that at higher injection pressures the flow power and the expansion power are more. Due to

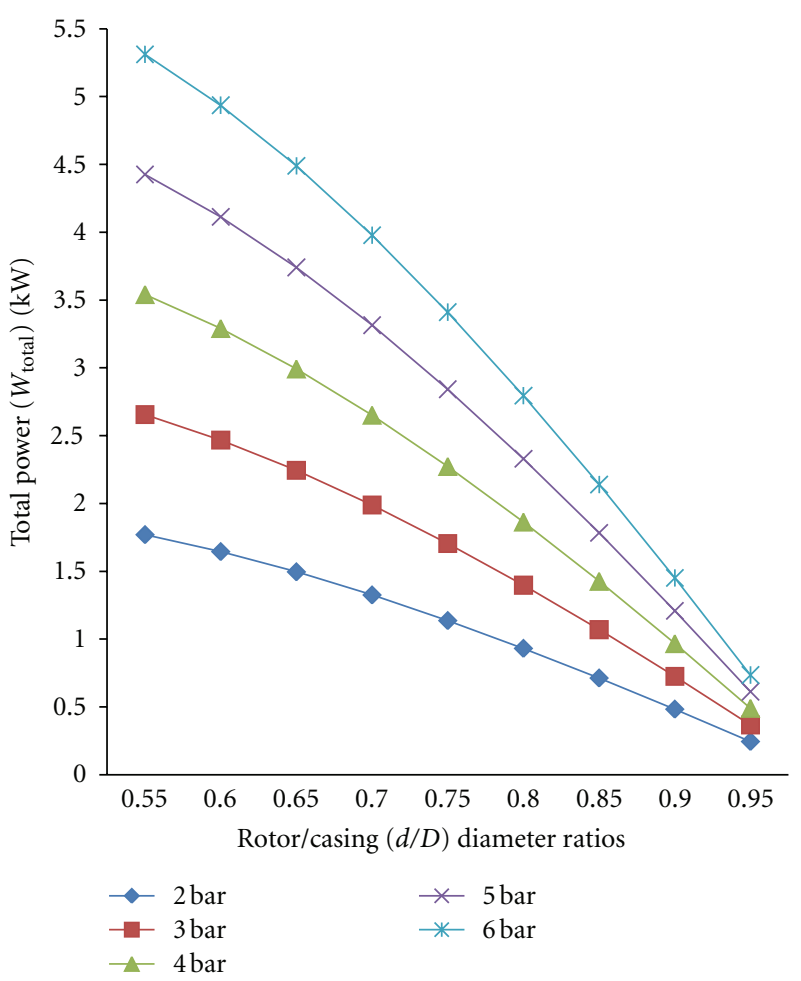

FIGURE 7: Total power output versus rotor/casing diameter $(d / D)$ ratio when $D=100 \mathrm{~mm}$.

higher admission pressure total amount of air admitted is more and it offers the overall increase in total power output.

Figure 10 shows that the experimental values of power output increase with higher injection pressure and at different speeds of rotation. Comparison of power output for theoretical and experimental conditions shows that for a given injection pressure the experimental power output is less than theoretical value at same operating condition. This is because of leakage at interface of vane and casing, throttling of air at admission, and friction losses. From Figures 9 and 10 the theoretical performance of the air turbine can be compared with the experimental performance. It is seen that the results obtained experimentally match significantly with the theoretical results to the extent of around $70 \%$ to $98 \%$ for different operating parameters.

Figure 11 depicts the variation of performance efficiency of air turbine for different injection pressure at different speeds of rotation such as: $99 \%, 89.8 \%, 84.3 \%, 79.8 \%$, $76.5 \%$ and $72.5 \%$ at speed of rotation $500 \mathrm{rpm}, 1000 \mathrm{rpm}$, $1500 \mathrm{rpm}, 2000 \mathrm{rpm}, 2500 \mathrm{rpm}$, and $3000 \mathrm{rpm}$, respectively, when injection pressure varies from 2.8-4.2 bar. But the performance efficiency for injection pressure $1.4 \mathrm{bar}$ is not in parity with higher pressure. This indicates that turbine power output is utilized in overcoming the friction losses at injection pressure 1.4 bar and centrifugal forces on vanes are also not effective at speed of rotation 500-3000 rpm. Thus air turbine offers best performance at injection pressure 2.8 to 4.2 bar (40-60 psi). 


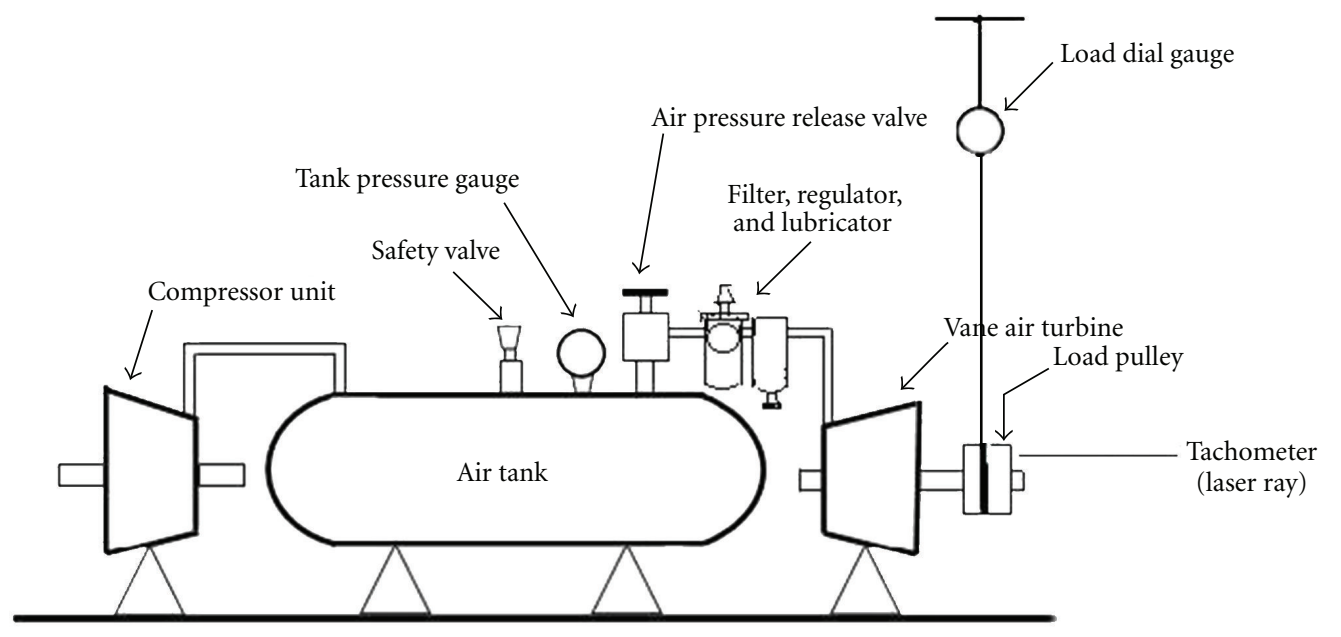

FIGURE 8: Schematic test setup.

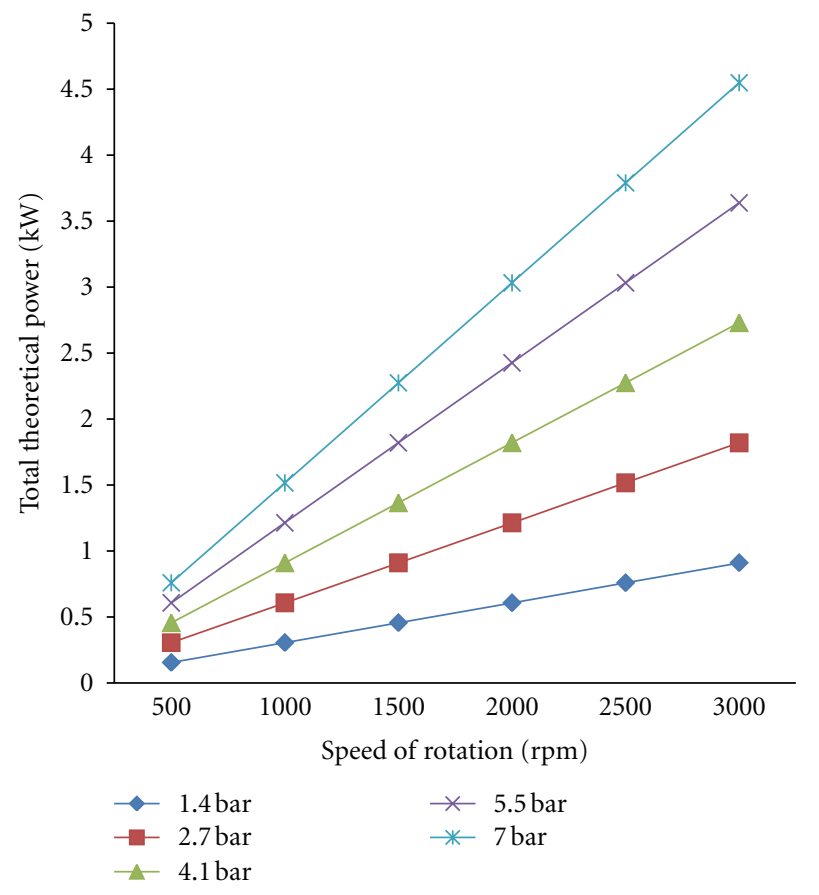

Figure 9: Total theoretical power output $\left(W_{\text {theo }}\right)$ versus speed of rotation.

\section{Revised Mathematical Model}

6.1. Reasons for Large Deviation between Theoretical and Experimental Results. The above study shows that there is large difference between the theoretical results and experimental observations ranging from $72.5 \%$ to $99 \%$. This is attributed due to the following reasons.

(i) Theoretically expansion is considered to be adiabatic but the same will not be possible in this case as there is no isolation of engine from the surroundings. In actual case the expansion will not be adiabatic and

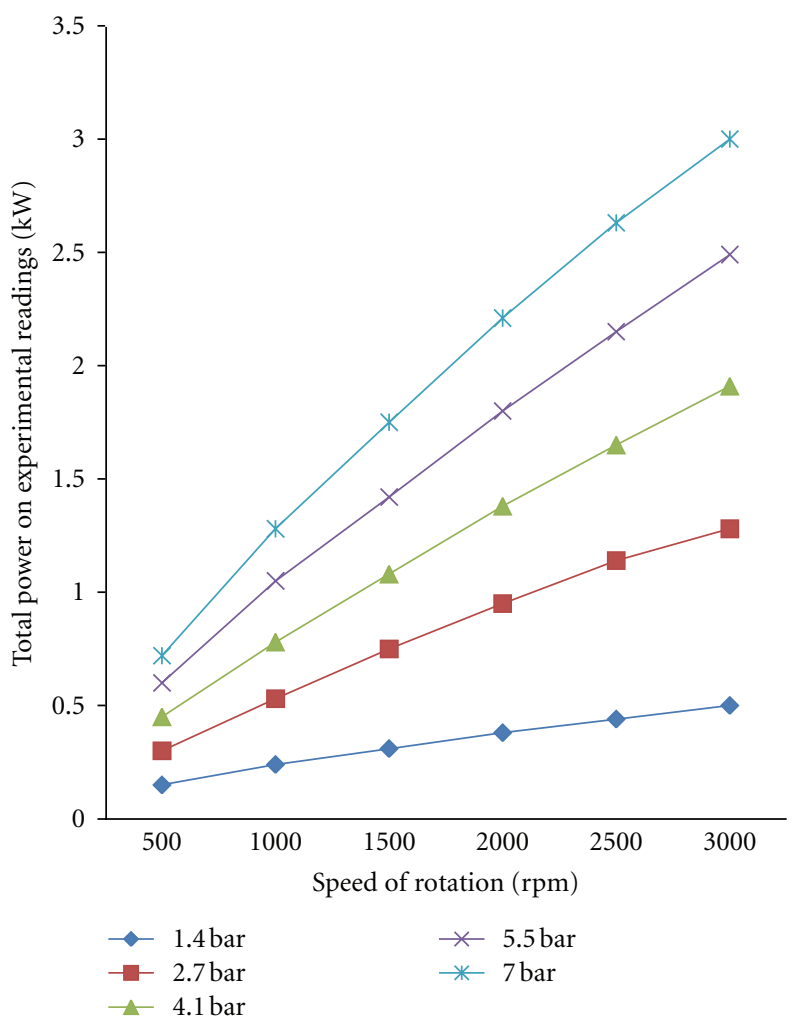

FIGURE 10: Total experimental power $\left(W_{\text {texper }}\right)$ versus speed of rotation.

the index of expansion will be different from 1.4 (i.e., theoretically considered value).

(ii) The leakage at interface of vane and casing cannot be completely eliminated in view of running clearance required between the mating surfaces. Although vanes are of spring-loaded type but the too high stiffness of vane spring will lead to an increase in friction resistance loss. This leakage can be experimentally 


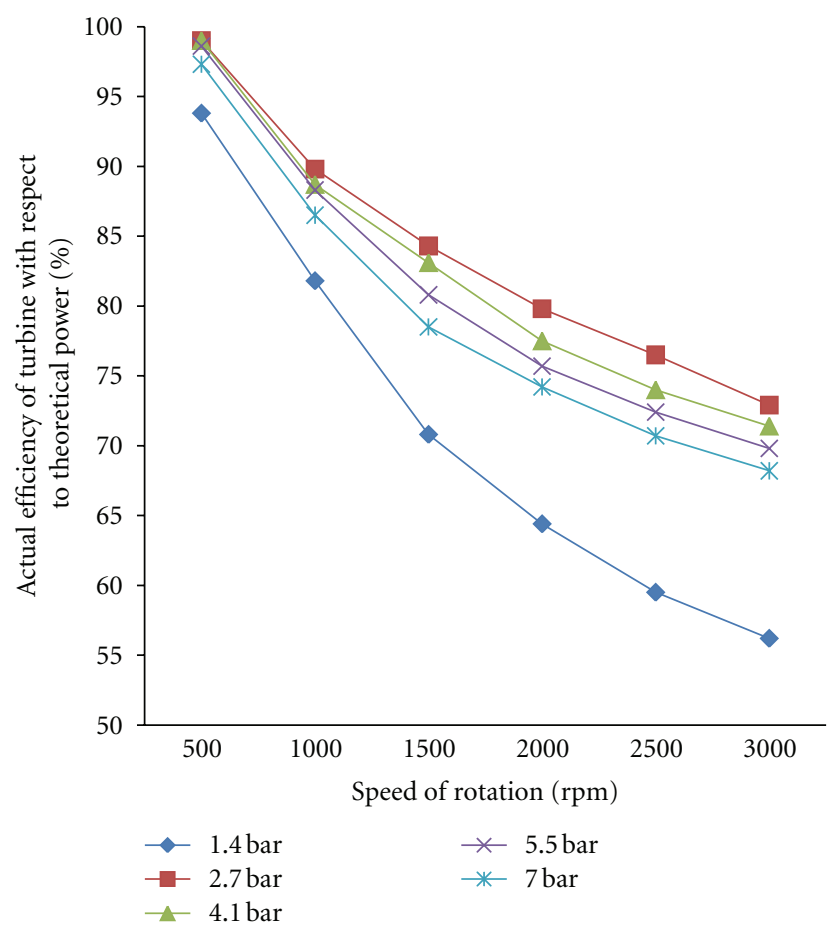

FIGURE 11: Actual performance of vane turbine with respect to theoretical power.

observed and suitable leakage model may be defined in future studies.

(iii) The throttling of air occurs at the time of admission due to restricted passage available for the injection of air into air turbine. This throttling effectively reduces the initial pressure at the beginning of expansion of air inside air turbine. Adverse influence of throttling at different injection pressures will be different and the output varies accordingly.

(iv) The friction losses which are there at all rotating parts and mating surfaces eventually reduce the power output from the engine. These losses are there at the mating surface of vanes/casing and at the shaft bearing.

(v) Air lubricator adds some trace of lubricants in the air injected into the air turbine. These traces of lubricant also expand with the expanding air, and the work output is different from theoretically predicted value.

(vi) The experimental observation errors may be there in various measurements.

Thus an empirical relation between tip leakage and throttling losses due to effect of size of air nozzles for different injection pressure and speed of rotation which ultimately varies the air consumption, is taken into account to reduce this large deviations between the theoretical and experimental results.
The modified model in correlation with (1) is given below:

$$
\begin{aligned}
& W_{\text {total modified }}= \cdot\left(\frac{N_{i}}{60}\right) \cdot\left(\frac{\gamma}{\gamma-1}\right) \\
& \cdot\left\{1-\left(\frac{p_{4}}{p_{i}}\right)^{(\gamma-1) / \gamma}\right\} p_{i} \\
& \cdot\left[L \cdot\left\{\frac{\left(X_{1 \min }+X_{2 \min }\right) \cdot\left(d+X_{1 \min }\right)}{4}\right\}\right. \\
&\cdot \sin \theta]+n \cdot\left(\frac{N_{i}}{60}\right) \cdot\left(p_{4}-p_{5}\right) \\
& \cdot\left[L \cdot \frac{\left(X_{1 \max }+X_{2 \max }\right) \cdot\left(d+X_{1 \mathrm{max}}\right)}{4}\right\} \\
&\cdot \sin \theta]-\left[\left\{0.13+0.06\left(\frac{p_{i}-p_{0}}{p_{0}}\right)\right\}\right. \\
& \cdot\left(\frac{N_{i}}{N_{0}}\right)-\{0.13] \\
&\left.+0.07\left(\frac{p_{i}-p_{0}}{p_{0}}\right)\right\}
\end{aligned}
$$

where $p_{0}=20 \mathrm{psi}, p_{i}=20 \ldots 100 \mathrm{psi}$, and $N_{0}=500 \mathrm{rpm}, N_{i}=$ $500 \ldots 3000 \mathrm{rpm}$

6.2. Results and Discussion. With modified theoretical model observations have been recorded in the Table 2 and it is plotted in the Figure 12. Now it is seen that the theoretical results are now closer to the experimental results as shown in the Figure 10.

Now the performance efficiency of air turbine with modified model in comparison to experimental data is recorded as shown in Table 3. The Figure 13 shows that the variation of performance efficiency of air turbine is ranging from:

(i) $95.8 \%$ to $86.7 \%$ at injection pressure 2.7 bar ( 40 psi) and is lowest $86.7 \%$ at speed of rotation $3000 \mathrm{rpm}$;

(ii) $99.6 \%$ to $90.6 \%$ at injection pressure 4.1 bar (60 psi);

(iii) $100 \%$ to $91.7 \%$ at injection pressure 4.1 bar (60 psi);

(iv) $99.6 \%$ to $91.5 \%$ at injection pressure 4.1 bar (60 psi).

The results at injection pressure 1.4 bar (20 psi) are not compared as at 1.4 bar air turbine only overcomes the frictional losses and it starts running.

From Figure 13 it is also seen that performances at injection pressure 4.1 bar to 7 bar are very close ranging from $100 \%$ to $91.5 \%$.

\section{Conclusions}

From the above study, it is seen that modified model is closer to the experimental results. Based on the input parameters considered and various investigations carried out, following conclusions are drawn. 
TABLe 2: Modified theoretical power $\left(W_{\text {total-modified }}\right)$ at $D=100 \mathrm{~mm}, d=75 \mathrm{~mm}$, vane angle $(\theta)=45^{\circ}$, injection angle $(\phi)=60^{\circ}, L=45 \mathrm{~mm}$ at injection pressure $20-100$ psi.

\begin{tabular}{|c|c|c|c|c|c|c|}
\hline \multirow{2}{*}{ Injection pressure $p_{1} \downarrow$} & \multicolumn{6}{|c|}{ Total modified theoretical power, $\mathrm{kW}$} \\
\hline & $500 \mathrm{rpm}$ & $1000 \mathrm{rpm}$ & $1500 \mathrm{rpm}$ & $2000 \mathrm{rpm}$ & $2500 \mathrm{rpm}$ & $3000 \mathrm{rpm}$ \\
\hline 1.4 bar (20 psi) & 0.151 & 0.303 & 0.454 & 0.606 & 0.757 & 0.909 \\
\hline 2.7 bar (40 psi) & 0.303 & 0.565 & 0.799 & 1.042 & 1.286 & 1.529 \\
\hline 4.1 bar (60 psi) & 0.475 & 0.809 & 1.144 & 1.478 & 1.813 & 2.148 \\
\hline 5.5 bar ( 80 psi) & 0.636 & 1.062 & 1.489 & 1.915 & 2.341 & 2.768 \\
\hline 7.0 bar $100 \mathrm{psi}$ ) & 0.798 & 1.315 & 1.834 & 2.351 & 2.869 & 3.387 \\
\hline
\end{tabular}

TABLE 3: Actual performance versus speed of rotation.

\begin{tabular}{|c|c|c|c|c|c|c|}
\hline \multirow{2}{*}{ Injection pressure } & \multicolumn{6}{|c|}{ Performance efficiency of model (in \%ge) } \\
\hline & $500 \mathrm{rpm}$ & $1000 \mathrm{rpm}$ & $1500 \mathrm{rpm}$ & $2000 \mathrm{rpm}$ & $2500 \mathrm{rpm}$ & $3000 \mathrm{rpm}$ \\
\hline 2.7 bar (40 psi) & $95.80 \%$ & $97.80 \%$ & $95.80 \%$ & $92.80 \%$ & $90.10 \%$ & $86.70 \%$ \\
\hline 4.1 bar (60 psi) & $94.70 \%$ & $99.60 \%$ & $99.00 \%$ & $95.30 \%$ & $92.70 \%$ & $90.60 \%$ \\
\hline 5.5 bar ( 80 psi) & $94.00 \%$ & $100.00 \%$ & $98.60 \%$ & $95.80 \%$ & $93.70 \%$ & $91.70 \%$ \\
\hline 7.0 bar (100 psi) & $92.30 \%$ & $99.60 \%$ & $97.20 \%$ & $95.60 \%$ & $93.30 \%$ & $91.50 \%$ \\
\hline
\end{tabular}

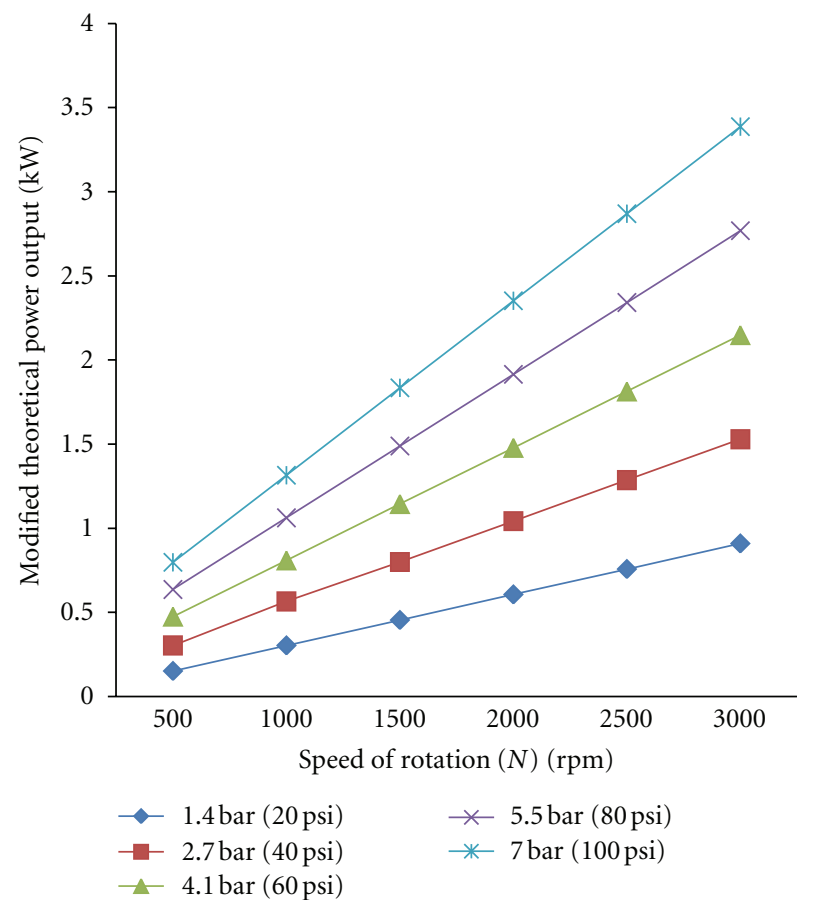

FIGURE 12: Modified theoretical power output ( $\left.W_{\text {total-modified }}\right)$ versus speed of rotation.

(i) The total power output developed is found maximum at speed of rotation $3000 \mathrm{rpm}$ when air consumption is maximum.

(ii) The performance efficiency of the novel air turbine is optimum at $1000 \mathrm{rpm}$ when air consumption is minimum, at rotor/casing diameter ratio 0.70 , injection pressure 4.1 bar to 7.0 bar.

(iii) The theoretical optimum shaft power output is significantly matching with experimental results and

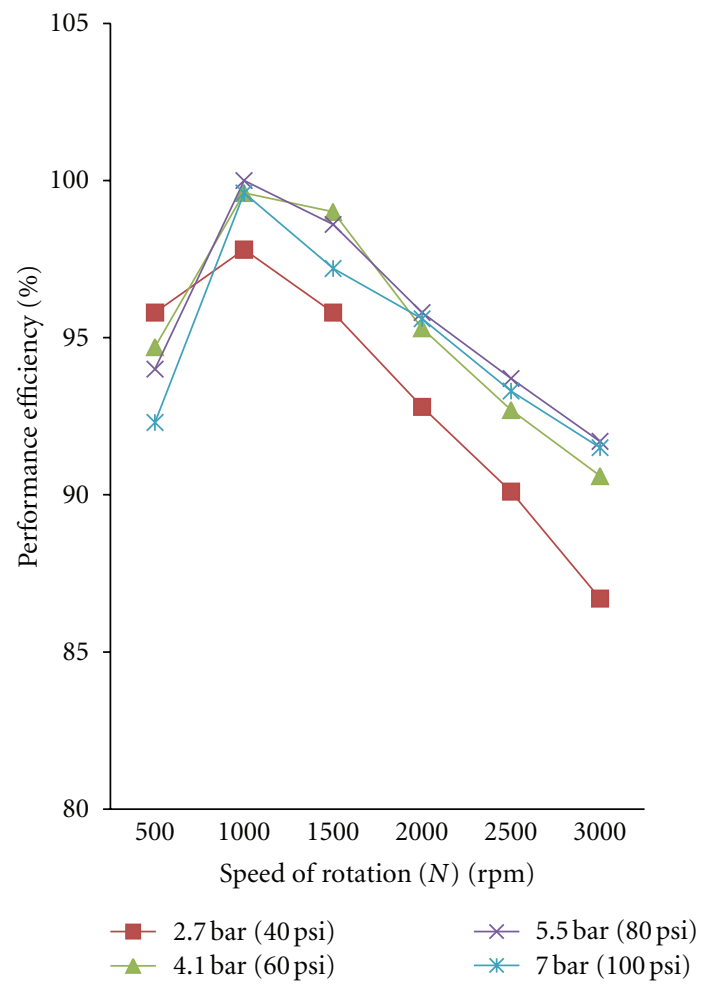

FIgURE 13: Performance of vane turbine with respect to modified theoretical model.

performance efficiency of the novel air turbine ranges from $91 \%$ to $100 \%$ at injection pressure $4.1-7.0$ bar.

Thus the above investigation shows that such data could be useful for designing the air engine for light vehicles/ motorbikes which could be helpful in curbing the environmental issues to large extent if implemented widely. 


\section{Nomenclature}

$d$ : Diameter of rotor $(2 r)$ in meter

$D$ : Diameter of outer $(2 R)$ cylinder in meter

$L$ : $\quad$ Length of rotor having vanes in meter

$n: \quad$ No. of vanes $=(360 / \theta)$

$N$ : $\quad$ No. of revolution per minute

$p_{1}, v_{1}$ : Pressure and volume, respectively, at which air strike the turbine

$p_{4}, v_{4}$ : Pressure and volume, respectively, at which maximum expansion of air takes place

$p_{5}: \quad$ Pressure at which turbine releases the air to atmosphere.

$v: \quad$ Volume in cu-m

$w$ : Theoretical work output in $\mathrm{Nm}$

$W: \quad$ Theoretical power output $(\mathrm{Nm} / \mathrm{s})$

$X_{1 i}$ : Variable extended lengths of vane at point 1 , where $i=\min$ or $\max$ )

$X_{2 i}$ : Variable extended lengths of vane at point 2, where $i=\min$ or $\max$

\section{Subscripts}

$\begin{array}{ll}\text { 1,2 . 4, 5: } & \text { Subscripts indicate the positions of } \\ & \text { vanes in casing } \\ e, \text { exp: } & \text { Expansion } \\ f, \text { flow: } & \text { Flow } \\ \text { min: } & \text { Minimum } \\ \text { max: } & \text { Maximum } \\ t, \text { total: } & \text { Total } \\ \text { ttheor: } & \text { Total theoretical } \\ \text { texper: } & \text { Total experimental } \\ \text { total-modified: } & \text { Total modified }\end{array}$

Greek Symbols

$\gamma: 1.4$ for air

$\theta$ : Angle between 2 vanes

$\phi$ : Angle at which compressed air enters into rotor through nozzle.

\section{References}

[1] M. K. Hubbert, "Nuclear energy and the fossil fuels," in Proceedings of the Spring Meeting, Drilling and Production Practice, pp. 7-25, American Petroleum Institute, San Antonio, Tex, USA, 1956.

[2] K. Aleklett and C. J. Campbell, "The peak and decline of world oil and gas production," Minerals and Energy, Raw Materials Report, vol. 18, no. 1, pp. 5-20, 2003.

[3] B. R. Singh and O. Singh, "Use of non-conventional energy for sustainability to fossil fuel," in Proceedings of the RAME National Conference on Recent Trend on Mechanical Engineering, Etawah-Proceedings, pp. 130-136, Baba Sahab Dr. Bhim Rao Ambedkar College of Agricultural Engineering and Technology, March 2007.

[4] B. R. Singh and O. Singh, "Uses of wind power as a non-conventional/renewable energy for sustainability," in Proceedings of the STEM National Conference on State of Art Technology in Mechanical Engineering, UP-Proceedings, pp. 503-515, College of Technology, G.B. Pant University, Pant Nagar, India, October 2007.

[5] E. J. Honton, "Hydrogen fuel cell car," in Proceedings of the 15th Annual US Conference and Hydrogen Expo, Los Angeles, Calif, USA, April 2004.

[6] R. Robert and W. J. Vincent, Fuel Cell Vehicle World Survey 2003, Breakthrough Technologies Institute, Washington, DC, USA, 2004.

[7] B. R. Singh and O. Singh, "Necessity and potential for biodiesel use in India," in Proceedings of the International Conference on Bio-Fuel Vision-2015, pp. 71-89, Bikaner, India, October 2006.

[8] B. R. Singh and O. Singh, "Study of compressed air as an alternative to fossil fuel for automobile engines," in Proceedings of the International Conference on Challenges and Strategies for Sustainable Energy and Environment, UP-Proceedings, pp. 179-191, Lucknow, India, June 2006.

[9] B. R. Singh and O. Singh, "A study on sustainable energy sources and its conversion systems towards development of an efficient zero pollution novel turbine to be used as primemover to the light vehicle," in Proceedings of the ASME International Mechanical Engineering Congress and Exposition (IMECE 08), Boston, Mass, USA, Paper no. IMECE-200866803, October 2008.

[10] N. Guy and N. Cyril, "Compressed air-the most sustainable energy carrier for community vehicles," Speech in front of assembly at Kultur gathered for Fuel Cells World 2004.

[11] G. Saint Hilaire, R. Saint Hilaire, and Y. Saint Hilaire, "Quasiturbine zero pollution car using gasoline," Festival at Le Lundi, Montreal Gazette, September 2005.

[12] B. R. Singh and O. Singh, "Development of a vaned type novel air turbine," International Journal of Mechanical Engineering Science, vol. 222, no. 12, pp. 2419-2426, 2008.

[13] O. Badr, P. W. O'Callaghan, M. Hussein, and S. D. Probert, "Multi-vane expanders as prime movers for low-grade energy organic rankine-cycle engines," Applied Energy, vol. 16, no. 2, pp. 129-146, 1984.

[14] O. Badr, P. W. O'Callaghan, and S. D. Probert, "Multi-vane expander performance: breathing characteristics," Applied Energy, vol. 19, no. 4, pp. 241-271, 1985.

[15] O. Badr, S. D. Probert, and P. W. O'Callaghan, "Multi-vane expanders: vane dynamics and friction losses," Applied Energy, vol. 20, no. 4, pp. 253-285, 1985.

[16] O. Badr, P. W. O'Callaghan, and S. D. Probert, "Multi-vane expanders: geometry and vane kinematics," Applied Energy, vol. 19, no. 3, pp. 159-182, 1985.

[17] O. Badr, S. D. Probert, and P. W. O'Callaghan, "Multi-vane expanders: internal-leakage losses," Applied Energy, vol. 20, no. 1, pp. 1-46, 1985.

[18] O. Badr, S. D. Probert, and P. W. O'Callaghan, "Performances of multi-vane expanders," Applied Energy, vol. 20, no. 3, pp. 207-234, 1985.

[19] O. Badr, S. D. Probert, and P. W. O'Callaghan, "Influences of vane design and lubricant on a multi-vane expander's performance," Applied Energy, vol. 22, no. 4, pp. 271-298, 1986.

[20] O. Badr, S. D. Probert, and P. W. O’Callaghan, “Optimal design and operating conditions for a multi-vane expander," Applied Energy, vol. 24, no. 1, pp. 1-27, 1986.

[21] O. Badr, D. Probert, and P. W. O'Callaghan, "Selection of operating conditions and optimisation of design parameters for multi-vane expanders," Applied Energy, vol. 23, no. 1, pp. $1-46,1986$. 
[22] B. Yang, X. Peng, Z. He, B. Guo, and Z. Xing, "Experimental investigation on the internal working process of a $\mathrm{CO}_{2}$ rotary vane expander," Applied Thermal Engineering, vol. 29, no. 1112, pp. 2289-2296, 2009.

[23] K. D. Huang and S. C. Tzeng, "Development of a hybrid pneumatic-power vehicle," Applied Energy, vol. 80, no. 1, pp. 47-59, 2005.

[24] K. D. Huang, S. C. Tzeng, W. P. Ma, and W. C. Chang, "Hybrid pneumatic-power system which recycles exhaust gas of an internal-combustion engine," Applied Energy, vol. 82, no. 2, pp. 117-132, 2005.

[25] K. David Huang, K. V. Quang, and K. T. Tseng, "Study of recycling exhaust gas energy of hybrid pneumatic power system with CFD," Energy Conversion and Management, vol. 50, no. 5, pp. 1271-1278, 2009.

[26] K. David Huang, K. V. Quang, and K. T. Tseng, "Study of the effect of contraction of cross-sectional area on flow energy merger in hybrid pneumatic power system," Applied Energy, vol. 86, no. 10, pp. 2171-2182, 2009.

[27] H. J. van Antwerpen and G. P. Greyvenstein, "Use of turbines for simultaneous pressure regulation and recovery in secondary cooling water systems in deep mines," Energy Conversion and Management, vol. 46, no. 4, pp. 563-575, 2005.

[28] D. Wei, X. Lu, Z. Lu, and J. Gu, "Performance analysis and optimization of organic rankine cycle (ORC) for waste heat recovery," Energy Conversion and Management, vol. 48, no. 4, pp. 1113-1119, 2007.

[29] J. M. Tournier and M. S. El-Genk, "Axial flow, multi-stage turbine and compressor models," Energy Conversion and Management, vol. 51, no. 1, pp. 16-29, 2010.

[30] B. Yang, X. Peng, Z. He, B. Guo, and Z. Xing, "Experimental investigation on the internal working process of a $\mathrm{CO}_{2}$ rotary vane expander," Applied Thermal Engineering, vol. 29, no. 1112, pp. 2289-2296, 2009.

[31] J. Nickl, G. Will, H. Quack, and W. E. Kraus, "Integration of a three-stage expander into a $\mathrm{CO}_{2}$ refrigeration system," International Journal of Refrigeration, vol. 28, no. 8, pp. 1219-1224, 2005.

[32] A. Subiantoro and K. T. Ooi, "Analytical study of the endface friction of the revolving vane mechanism," International Journal of Refrigeration, vol. 34, no. 5, pp. 1276-1285, 2011.

[33] Y. T. Shen and Y. R. Hwang, "Design and implementation of an air-powered motorcycles," Applied Energy, vol. 86, no. 7-8, pp. 1105-1110, 2009.

[34] B. R. Singh and O. Singh, "A concept for development of a vaned type novel air turbine," in Proceedings of the 12th International Symposium on Transport Phenomena and Dynamics of Rotating Machinery (ISROMAC '08), Pacific Center of Thermal-Fluids Engineering, Sheraton Mohana Surfrider Hotel, Honolulu, Hawaii, USA, Paper no. ISROMAC-1220046, February 2008.

[35] B. R. Singh and O. Singh, "Energy storage system to meet challenges of 21st century-an overview," in Proceedings of the All India Seminar on Energy Management in Perceptive of Indian Scenario, Lucknow-Proceedings, chapter 15, pp. 157167, Institution of Engineer, State Centre, Engineer's Bhawan, Lucknow, India, October 2008.

[36] B. R. Singh and O. Singh, "A study to optimize the output of vaned type novel air turbine," in Proceedings of the 4th International Conference on Energy Research and Development (ICERD '08), State of Kuwait, Kuwait, Paper no. ICERD-41353, November 2008.
[37] B. R. Singh and O. Singh, "Parametric evaluation of vane angle on performance of novel air turbine," SITM Journal of Science, Engineering and Management, vol. 2, pp. 7-18, 2008.

[38] B. R. Singh and O. Singh, "Analytical study on a vaned type novel air turbine for different conditions of casing and rotor diameters," in Proceedings of the ASME International Conference on Energy Sustainability (ES '09), vol. 1, pp. 699-706, San Francisco, Calif, USA, Paper no. ES2009-90207, July 2009.

[39] B. R. Singh and O. Singh, "Applications of compressed air as an alternative energy to meet challenges of 21st centuryglobal warming," in Proceedings of the International Conference on Engineering Congress on Alternatives Energy Applications: Option or Necessity? (EC '09), State of Kuwait, Kuwait, Paper no. EC2009-1082, November 2009.

[40] B. R. Singh and O. Singh, "Parametric evaluations of injection angles and vane angles on performance of a vaned type novel air turbine," International Journal of Engineering and Physical Sciences, vol. 3, no. 4, pp. 226-233, 2009.

[41] B. R. Singh and O. Singh, "Optimization of power output of a vaned type novel air turbine with respect to different injection angles-under ideal adiabatic expansion," The International Journal of Manufacturing Excellence, vol. 2, no. 2, pp. 205-211, 2009.

[42] B. R. Singh and O. Singh, "Numerical analysis of pressure admission angle to vane angle ratios on performance of a vaned type novel air turbine," International Journal of Engineering and Applied Sciences, vol. 6, no. 2, pp. 94-101, 2010.

[43] B. R. Singh and O. Singh, "Theoretical investigations on different casing and rotor diameters ratio to optimize shaft output of a vaned type air turbine," International Journal of Engineering and Applied Sciences, vol. 6, no. 2, pp. 102-109, 2010.

[44] B. R. Singh and O. Singh, "Effect of rotor to casing ratios with different rotor vanes on performance of shaft output of a vane type novel air turbine," International Journal of Engineering and Applied Sciences, vol. 6, no. 4, pp. 217-222, 2010.

[45] B. R. Singh and O. Singh, "Effect of different vane angle on rotor-casing diameter ratios to optimize the shaft output of a vaned type novel air turbine," International Journal of Engineering Science and Technology, vol. 2, no. 3, pp. 114-121, 2010.

[46] B. R. Singh and O. Singh, "Study of effect of injection angle to rotor-casing diameter ratios on performance of a vaned type novel air turbine," International Journal of Engineering Science and Technology, vol. 2, no. 4, pp. 409-417, 2010.

[47] B. R. Singh and O. Singh, "Critical effect of rotor vanes with different injection angles on performance of a vaned type novel air turbine," International Journal of Engineering Science and Technology, vol. 2, no. 2, pp. 118-123, 2010.

[48] B. R. Singh and O. Singh, "Study of influence of vane angle on shaft output of a multi vane air turbine," International Journal of Renewable and Sustainable Energy, vol. 2, no. 3, pp. 033101033116, 2010.

[49] B. R. Singh and O. Singh, "Analytical investigations on different air injection angles to optimize power output of a vaned type air turbine," Internatinal Journal of Power and Energy, vol. 224, no. 3, pp. 305-312, 2010.

[50] B. R. Singh and O. Singh, "Study of effect of rotor vanes to rotor-casing dimensions on performance of a zero pollution vane type novel air turbine," International Journal of the Physical Sciences, vol. 5, no. 5, pp. 547-556, 2010.

[51] O. Singh, "Reciprocating and rotary compressor," in Applied Thermodynamics, pp. 797-798, New Age International, New Delhi, India, 2009. 

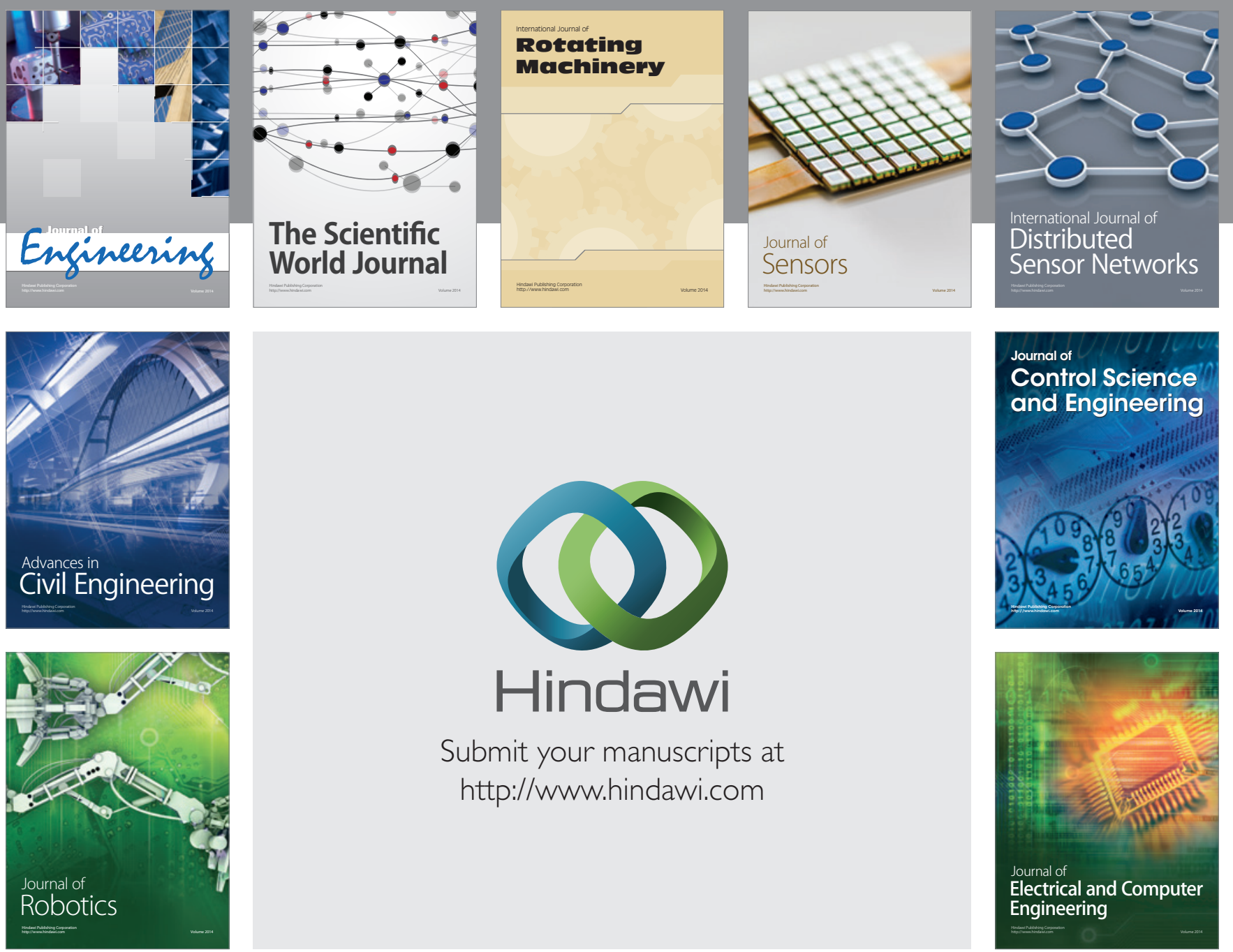

Submit your manuscripts at

http://www.hindawi.com
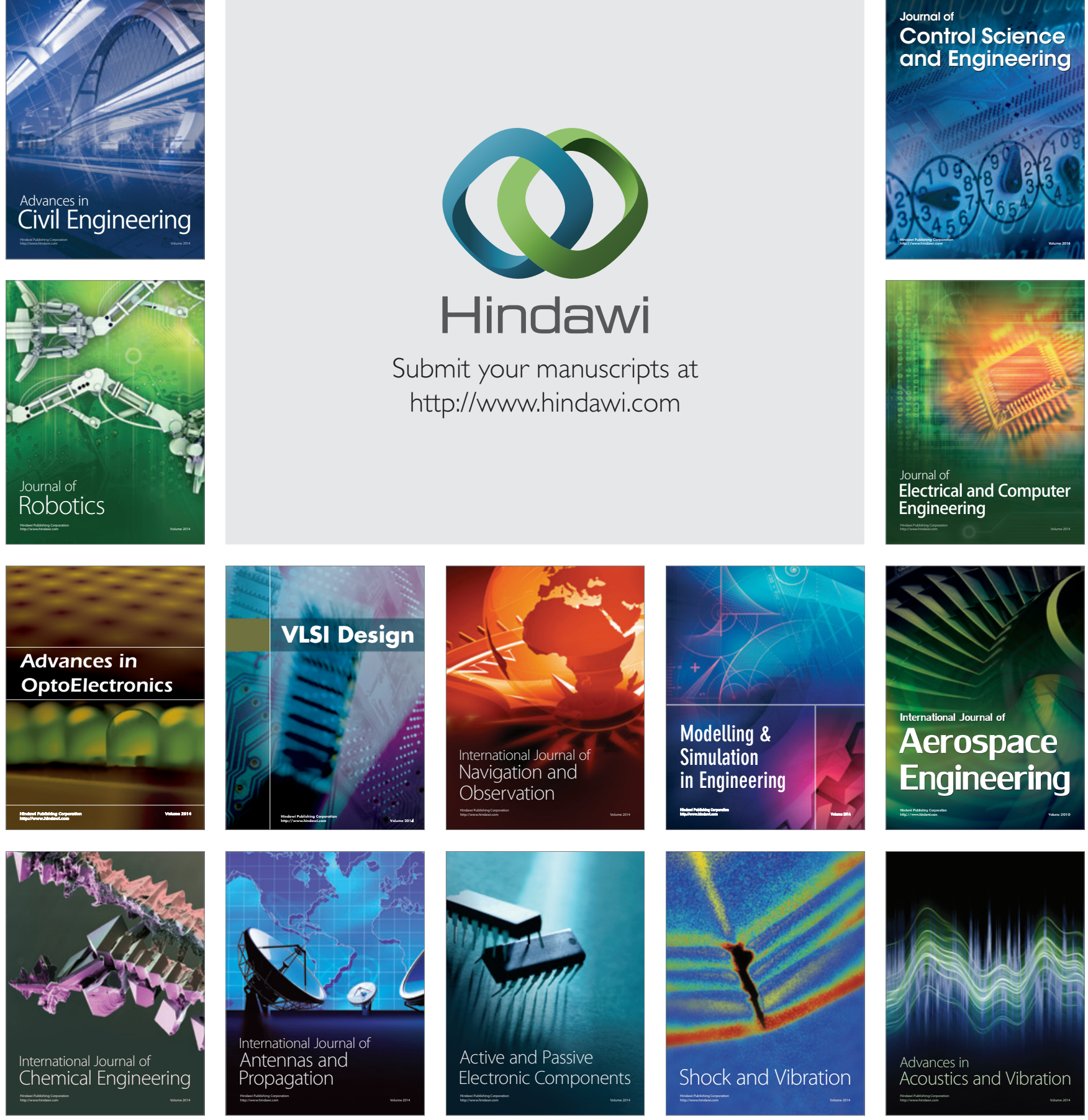